\title{
人間ドックに拈ける腹部超音波検査の泌尿器疾患に対する意義
}

\author{
1）水戸済生会総合病院泌尿器科（主任：野口良輔部長） \\ 2) 筑波大学臨床医学系泌尿器科 (主任: 小磯謙吉教授) \\ 関戸 哲利 ${ }^{1)}$ 鳥居 徹 ${ }^{2)}$ 野口 良輔 ${ }^{1)}$ \\ 赤座 英之 ${ }^{2)}$ 小磯 謙吉 ${ }^{2)}$
}

\section{TRANSABDOMINAL ULTRASONOGRAPHY FOR DETECTION OF UROLOGIC DISEASES IN THE GENERAL HEALTH CHECK}

\author{
Noritoshi Sekido ${ }^{1)}$, Toru Shimazui ${ }^{2)}$, Ryosuke Noguchii"), Hideyuki Akaza ${ }^{2)}$ and Kenkichi Koiso ${ }^{2)}$ \\ ${ }^{1}$ Department of Urology, Mito Saiseikai General Hospital \\ (Chief: Ryosuke Noguchi) \\ ${ }^{2}$ Department of Urology, Institute of Clinical Medicine, University of Tsukuba \\ (Chief: Prof. Kenkichi Koiso)
}

From August, 1989 to December, 1992, 11, 386 indivisuals consisting of 6,981 males and 4,405 females were examined in the general health check at Mito Saiseikai general hospital. Occult blood in dipstick urinalysis was detected in 190 of 6,981 males (2.7\%) and 503 of 4,405 females (11.4\%). Two renal cell carcinomas and ten bladder carcinomas were found out, but prostatic carcinoma could not be found out. None of these tumors were symptomatic. Two renal cell carcinomas, of which all patients had negative occult blood, were confirmed by computed tomography and angiography. Revealing the locally-confined tumor (Stage I) in the radiologic study, both tumors were resected with radical nephrectomy, and the pathological specimens showed pT2pNOpVO in both tumors. Of 10 bladder carcinomas seven transitional cell carcinomas, of which 6 patients had negative occult blood and one had positive occult blood, were confirmed by cystoscopy and TUR-BT. All of them were low-grade and low-stage tumors. Other three bladder carcinomas were detected by ultrasonography and cystoscopy, but these patient rejected TUR-BT. All of them had negative occult blood.

We consider that the transabdominal ultrasonography is a very useful test for detecting the early stage of renal cancer and superificial bladder cancer. We recommend that transabdominal ultrasonography involving the kidney and the lower urinary tract should be performed in the general health check.

Key words: general health check, renal cancer, bladder cancer

要旨：1989年 8 月から1992年12月までの 3 年 5 カ月間に水戸済生会総合病院健診センターを受診した 11,386名を対象とし，男女別に尿潜血陰性群・陽性群それぞれにつき経腹的超音波検查所見を集計した。 それをもとにして，尿潜血・経腹的超音波検査の泌尿器疾患一特に悪性腫瘍一の診断に対する有用性に ついて検討した，腎癌は 2 例発見されたが， 2 例とも無症候かつ尿潜血陰性で, Stage Iであり, 病理学 的にも pT2pN0pV0であり治癒切除が可能であった.膀胖癌は10例発見されたが, 手術を施行した 7 例は いずれも無症候で表在性かつ low-grade であった。膀胱癌10例中 1 例のみが尿潜血陽性であった。 また 尿細胞診を施行した 8 例は全て class II 以下であった。前立腺癌は 1 例も発見されなかった，以上より， 人間ドックにおける経腹的超音波検査は, 腎腫瘤性病変や表在性膀腅癌の早期診断に有用であると考兄 られ，非侵襲的で簡便な検査である点からも，腎臓・下部尿路の走査を含めてルーチンに行うべきであ ると思われた。 キーワード：人間ドック，腎癌, 膀胱癌 


\section{緒言}

泌尿器疾患のスクリーニングとしては集団検診での 尿検査が一般的であるが1)21，人間ドックでの腹部超音 波検査は，尿検査同様，被験者にとって非侵襲的で， その簡便性の点からも広く普及しており，泌尿器科領 域でもその有用性が報告されている3).

水戸済生会総合病院の人間ドックでは1989年 8 月に 腎及び下部尿路の腹部超音波検査を導入した所，腎癌 2 例，膀胱癌10例が発見された。今回，悪性腫瘍を中 心とする泌尿器疾患スクリーニングにおける超音波検 査の有用性を検討したので若干の文献的考察を加えて 報告する。

\section{対象及び方法}

対象は1989年 8 月から1992年12月までの 3 年 5 力月 間に水戸済生会総合病院健診センターを受診した 11,386名で，その内訳は，男性6,981名，女性4,405名 であった，受診者の年齢分布は男性が19９1歳（平均 47.13 歳), 女性が19～87歳 (平均46.96歳) で男女とも 30 ５0歳台に多く，受診者全体の平均年齢は 47.1 歳で あった（図 1 ).

検査の順序は図 2 の通り行われた。男性と女性で検 査の順序が若干異なっているが，女性の受診者は婦人 科検診時に膀胱を空虚にしておく必要があり, 当院人 間ドックが「日帰りドック」であることも関係して， 男女とも膀胼充満時に超音波検査ができるようなスケ ジュールを組んだ所，図 2 に示す通りとなった。検査 時に膀脱充満が不十分な受診者に対しては最後に再検 した。装置は東芝 SAL77B (3.75MHz コンベックス型 またはリニア型探触子）を用い，腹部超音波検査時に 腎・膀脱・前立腺（男性のみ）も走査した。超音波検 査は放射線科技師 (A.K.) により施行された。なお, 超音波検査施行時には，血液検査・尿検査等の結果は まだ出ていないため，超音波検査はこれらの情報のな い状態で施行された。

以上のようにして得られた超音波所見を男女それぞ れにつき尿潜血陽性群・陰性群に分けて集計した。な お，尿潜血は土ームス・マルティスティクス ${ }^{\circledR} \mathrm{SG}$ (マ イルス・三共株式会社）を用いて検査し十以上を陽 性, 一及び土を陰性とした。尿採取は，中間尿採取を説 明した後で受診者自身によって行われた。

\section{結果}

（1) 尿潜血陽性者数（図 1)

尿潜血陽性者数は男性が 190 人で男性受診者の $2.7 \%$ ，女性が503人で女性受診者の $11.4 \%$ 占め，全
図 1 年齢別受診者数

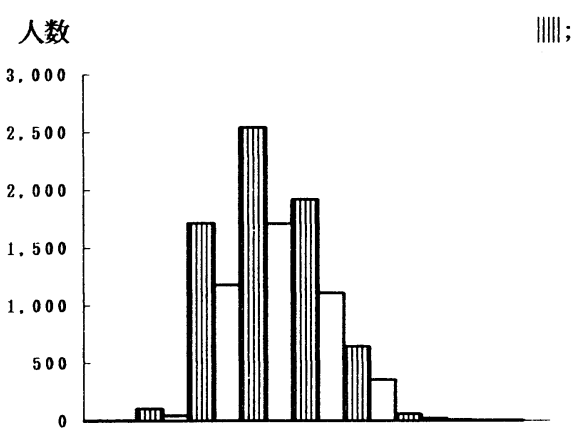

$\begin{array}{lllllllll}10 & 20 & 30 & 40 & 50 & 60 & 70 & 80 & 90\end{array}$ 年齢

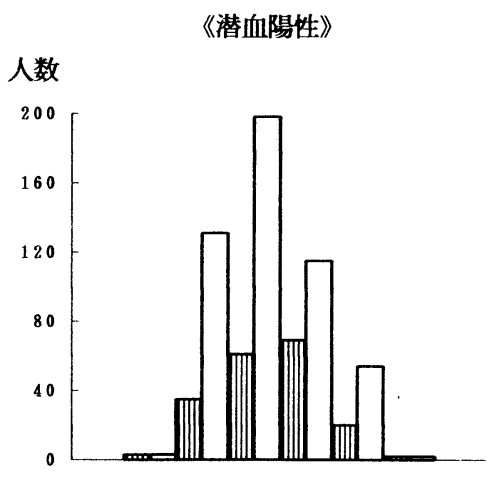

$\begin{array}{lllllll}20 & 30 & 40 & 50 & 60 & 70 & \text { 年齢 }\end{array}$

図 2 人間ドックの検査手順

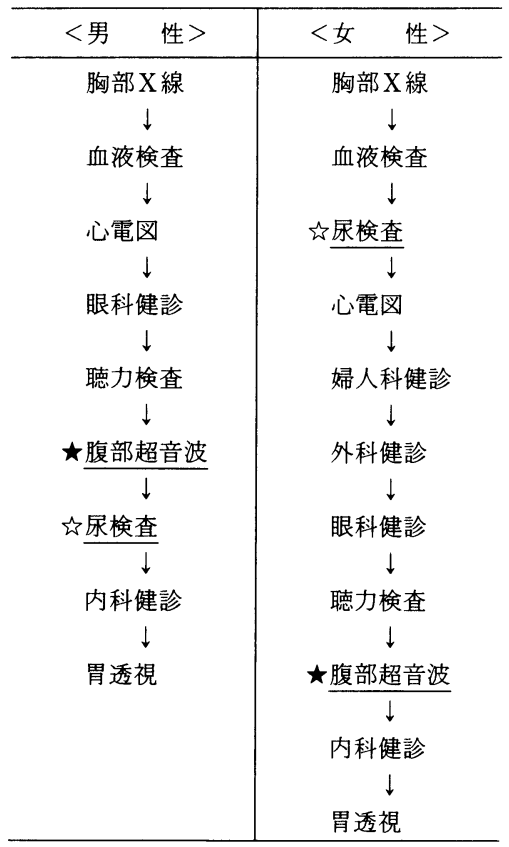


表 1 腎臓の経腹的超音波検查所見

\begin{tabular}{|c|c|c|c|c|c|}
\hline \multirow{2}{*}{ 潜 血 } & \multicolumn{2}{|c|}{ 男 } & \multicolumn{2}{|c|}{ 女 } & \multirow{2}{*}{ 合 計 } \\
\hline & 陰 性 & 陽 性 & 陰 性 & 陽 性 & \\
\hline 睡 瘍 & $\begin{array}{c}13 \\
(0.19)\end{array}$ & $(0.53)$ & $\begin{array}{c}7 \\
(0.18)\end{array}$ & $\begin{array}{c}2 \\
(0.40)\end{array}$ & $\begin{array}{c}23 \\
(0.20)\end{array}$ \\
\hline AML & $\begin{array}{c}10 \\
(0.15)\end{array}$ & $\begin{array}{c}1 \\
(0.53)\end{array}$ & $\begin{array}{c}3 \\
(0.08)\end{array}$ & $\begin{array}{c}1 \\
(0.20)\end{array}$ & $\begin{array}{c}15 \\
(0.13)\end{array}$ \\
\hline 水腎症 & $\begin{array}{c}31 \\
(0.51)\end{array}$ & $\begin{array}{c}3 \\
(1.58)\end{array}$ & $\begin{array}{c}29 \\
(0.74)\end{array}$ & $\begin{array}{c}8 \\
(1.60)\end{array}$ & $\begin{array}{c}71 \\
(0.62)\end{array}$ \\
\hline 結 石 & $\begin{array}{c}276 \\
(4.06)\end{array}$ & $\begin{array}{c}18 \\
(9.47)\end{array}$ & $\begin{array}{c}78 \\
(2.00)\end{array}$ & $\begin{array}{c}16 \\
(3.18)\end{array}$ & $\begin{array}{c}388 \\
(3.41)\end{array}$ \\
\hline 霊 胞 & $\begin{array}{c}722 \\
(10.6)\end{array}$ & $\begin{array}{c}32 \\
(16.8)\end{array}$ & $\begin{array}{c}180 \\
(4.61)\end{array}$ & $\begin{array}{c}29 \\
(5.77)\end{array}$ & $\begin{array}{c}963 \\
(8.46)\end{array}$ \\
\hline その他 & $\begin{array}{c}46 \\
(0.68)\end{array}$ & $\begin{array}{c}1 \\
(0.53)\end{array}$ & $\begin{array}{c}21 \\
(0.54)\end{array}$ & $\begin{array}{c}2 \\
(0.40)\end{array}$ & $\begin{array}{c}70 \\
(0.61)\end{array}$ \\
\hline
\end{tabular}

注；（）内は\%

$\mathrm{AML}=$ 腎血管筋脂胞腫

表 2 腫瘤性病変の再検結果

\begin{tabular}{lr|lr}
\hline 腎腫瘍(23例) & & 膀胱腫瘍 (20例) & \\
腎癌 & 2 & 膀胱癌 & 10 \\
異常なし & 6 & inverted papilloma & 1 \\
腎囊胞 & 3 & 異常なし & 3 \\
ベルタン柱 & 1 & 尿管間靸带 & 1 \\
fetal lobulation & 1 & 肉柱 & 1 \\
囊胞腎 & 1 & 腸管ガス & 1 \\
AML & 1 & 再受診せず & 3 \\
再受診せず & 8 & 前立腺腫痬 (1 例) & \\
AML(15例) & & 前立腺襄胞 & 1 \\
AML & 7 & & \\
異常なし & 3 & & \\
再受診せず & 5 & & \\
\hline
\end{tabular}

$\mathrm{AML}=$ 腎血管筋脂胞腫

体の受診者に占める割合は6.1\%（693人）であった。 尿潜血陽性者は各年齢層とも女性に多い傾向が認めら れた。

(2) 腎臓の超音波所見（表 1)

腎臓の超音波検查では，男女とも腎囊胞・腎結石が 多かった。

超音波検查上，腎腫瘍と診断されたのは23例で，こ の内 15 例が精查のために再受診 (再受診率 $65.2 \%$ ) し， 腎癌が 2 例発見された（全受診者の $0.02 \%$ ，再受診者 の13.3\%).その他の13例はベルタン柱等の偽陽性所見 であった（表 2 ）。代表的な偽陽性所見を図 3 に示した。 腎癌 2 例はいずれも無症状かつ尿潜血陰性であり, 遠 隔転移を認めず根治的腎摘出術を施行した（図 4 ・眼 5 ・表 3 ).

超音波検查上，腎血管筋脂肪腫 (以下 $\mathrm{AML}$ ) と䛦断 されたのは15例で，この内10例が精査のために再受診
図 3 腎腫瘍の偽陽性所見

左：51歳男性. 左腎上極に腫瘍と考えられる高エコー の病変を認めるが(矢印), 精査の結果 fetal lobulation であった．右：50歳男性．左腎の中央部に腫瘍と考克 られる低ェコーの病変を認めるが(矢印)，精査の結果 ベルタン柱であった。

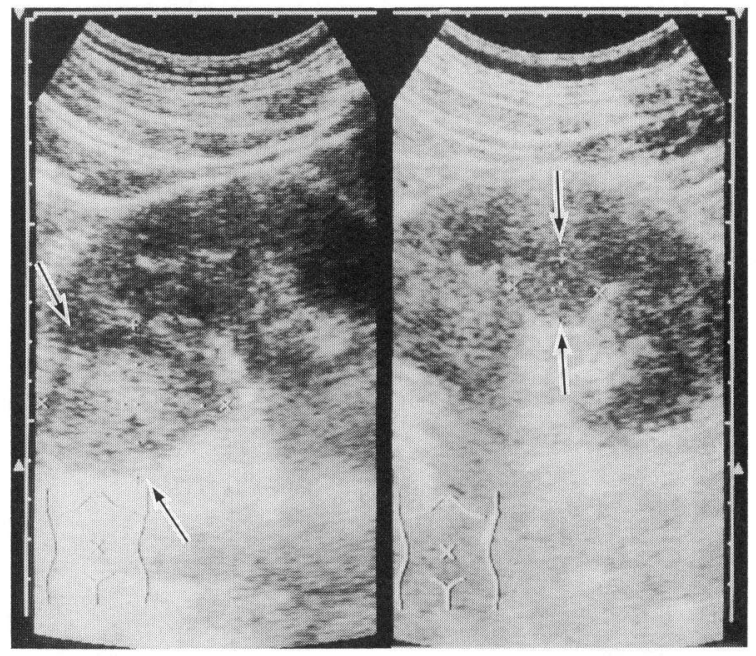

図 4 53歳男性. 右腎癌. 矢印の部分に腎臓に限局す る腫瘍を認める。超音波上は高エコーの病変として 描出されている。
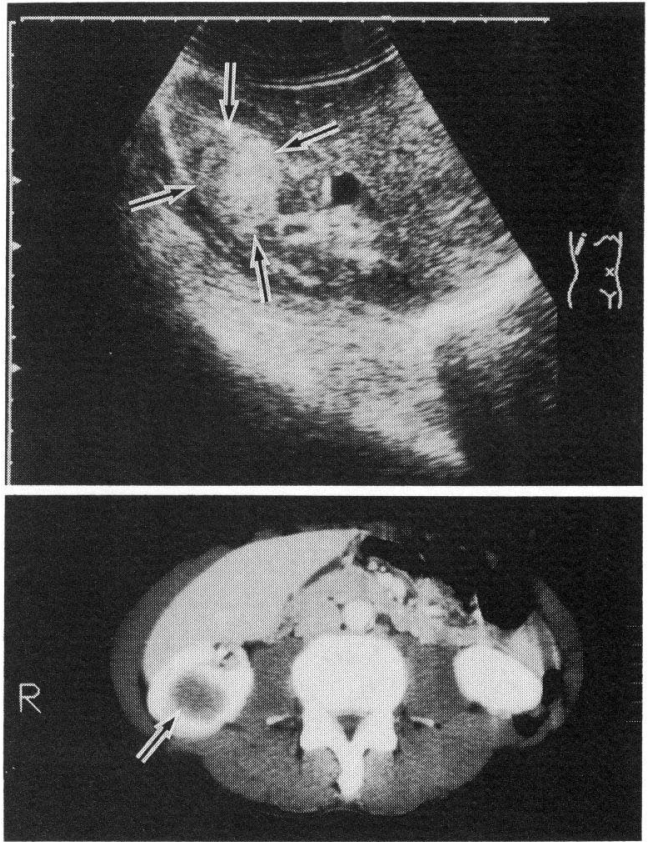
図 5 54歳男性. 左腎癌. 矢印の部分に腎臓に限局す る腫瘍を認める．超音波上は高ェコーの病変として 描出されている。
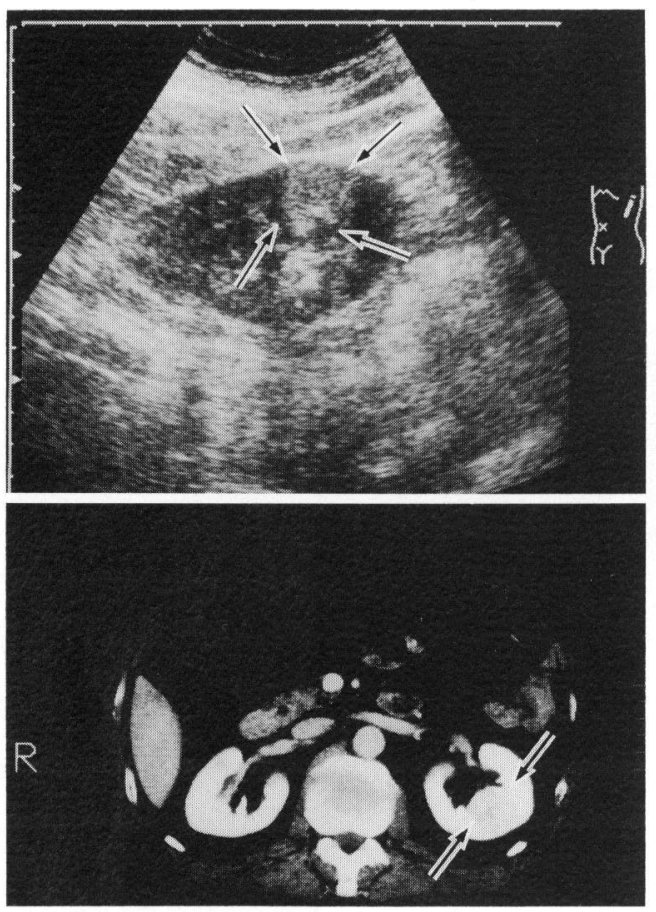

表 3 人間ドックで発見された腎癌

\begin{tabular}{|c|c|c|}
\hline 症 例 & 1 & 2 \\
\hline 年齢 性 & 53 男 & 54 男 \\
\hline Stage(Robson) & I & I \\
\hline 病 理 & pT2pNOpVO & pT2pNOpVO \\
\hline & $\begin{array}{l}\text { papillary type } \\
\text { G2 }\end{array}$ & $\begin{array}{l}\text { tubular type } \\
\text { clear cell subtype } \\
\text { G2 IFN } \beta\end{array}$ \\
\hline 潜 血 & - & - \\
\hline 尿細胞診 & I & III \\
\hline
\end{tabular}

した (再受診率 $66.7 \%)$ 。この10例の内，CT の結果之 合わせて AML と診断されたのは 7 例であり, 残り 3 例は再検查上異常は認められなかった。これに加えて, 腎腫瘍疑いのらち 1 例が CT の結果から AML と診断 され, AML は男性 5 例・女性 3 例の合計 8 例発見され （全受診者の $0.07 \%$ )，いずれも尿潜血陰性で結節性硬 化症は認められなかった。なおこの8例については, その後 6 力月〜 1 年毎に超音波検査と必要があれば CT 合わせて施行し経過観察を行っているが, 腫瘍 の増大や出血等が認められた症例はなかった。人間
図 6 45歳女性. 右腎の内側に腎蔵から突出する腫瘍 を認める(矢印)。超音波上は高ェコーで，CT 上は 脂肪濃度の腫瘍であることから AML と診断した。
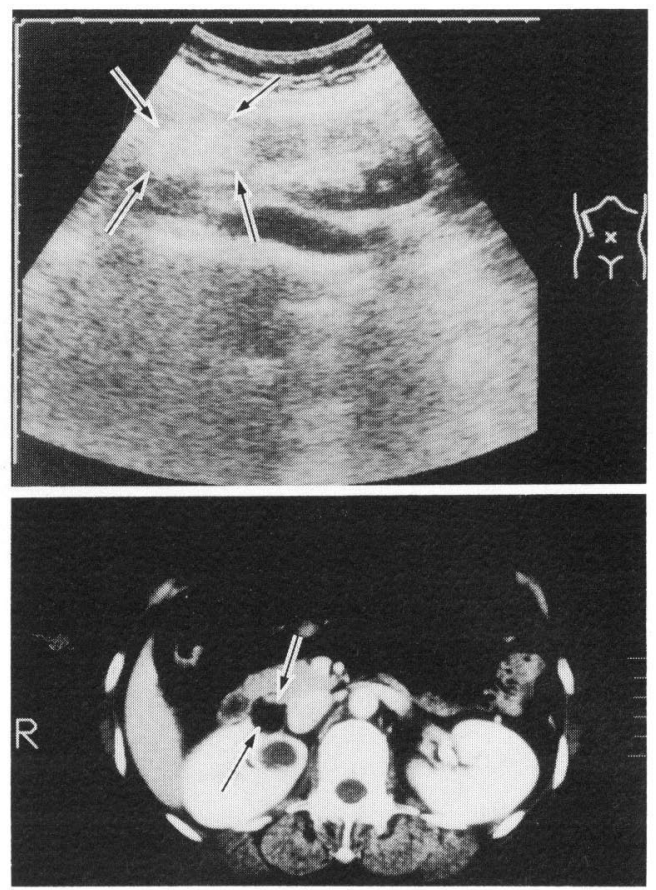

表 4 膀胱の経腹的超音波検查所見

\begin{tabular}{|c|c|c|c|c|c|}
\hline \multirow{2}{*}{ 潜 血 } & \multicolumn{2}{|c|}{ 男 } & \multicolumn{2}{|c|}{ 女 } & \multirow{2}{*}{ 合 計 } \\
\hline & 陰 性 & 陽 性 & 陰 性 & 陽 性 & \\
\hline 腫 瘍 & $\begin{array}{c}15 \\
(0.22)\end{array}$ & & $\begin{array}{c}4 \\
(0.10)\end{array}$ & $\begin{array}{c}1 \\
(0.20)\end{array}$ & $\begin{array}{c}20 \\
(0.18)\end{array}$ \\
\hline 結 石 & $\begin{array}{c}2 \\
(0.03)\end{array}$ & & $\begin{array}{c}1 \\
(0.03)\end{array}$ & & $\begin{array}{c}3 \\
(0.03)\end{array}$ \\
\hline 憩 室 & $\begin{array}{c}5 \\
(0.07)\end{array}$ & & $\begin{array}{c}9 \\
(0.23)\end{array}$ & & $\begin{array}{c}14 \\
(0.12)\end{array}$ \\
\hline その他 & $\begin{array}{c}8 \\
(0.12)\end{array}$ & $\begin{array}{c}3 \\
(1.58)\end{array}$ & $\begin{array}{c}4 \\
(0.10)\end{array}$ & & $\begin{array}{c}15 \\
(0.13)\end{array}$ \\
\hline
\end{tabular}

ドックで発見された AMLの 1 例を図 6 に示した。

(3) 膀胱の超音波所見 (表 4)

超音波検査上，膀胱腫瘍と診断されたのは20例で， この内17例が精査のために再受診した（再受診率 $85 \%$ )。この内 10 例が膀胱癌(全受診者の $0.09 \%$, 再受 診者の $58.8 \%$ )で， 1 例が inverted papilloma であり， 残り 6 例恃肉柱・尿管間勒帯・腸管ガス等の偽陽性所 見であった（表 2 ・図 7 )。膀胱腫瘍の症例の要約を表 5 に，代表的な超音波所見を図 8 に示した。手術を拒 否した 3 例（症例 $4 ， 6 ， 10 ）$ を除く 7 例に経尿道的 
表 5 人間ドックで発見された膀胱腫瘍

\begin{tabular}{|c|c|c|c|c|c|c|c|c|c|c|c|}
\hline 症 例 & 1 & 2 & 3 & 4 & 5 & 6 & 7 & 8 & 9 & 10 & 11 \\
\hline 年齢 性 & 64 男 & 39 男 & 56 男 & 45 男 & 55 男 & 51 男 & 39 男 & 60 男 & 61 男 & 51 男 & 49 男 \\
\hline 病 理 & G1 pTa & G1 pT1 & G1 pTa & 手術拒否 & G1 pTa & 手術拒否 & G1 pTa & G1 pTa & G1 pTa & 手術拒否 & 乳頭腫 \\
\hline 尿潜血 & - & - & - & - & - & - & - & - & + & - & - \\
\hline 库細胞診 & II & I & I & II & I & & I & I & II & & I \\
\hline
\end{tabular}

図 7 膀胱腫瘍の偽陽性所見

上：50歳男性. 膀胱腫瘍と考えられる小さな隆起性病 变を底部に認めるが(矢印), 精査の結果尿管間勒帯で あった。下：45歳女性. 膀胱腫瘍と考えられる隆起性 病変を右壁に認めるが(矢印)，精査の結果腸管ガスで あった。
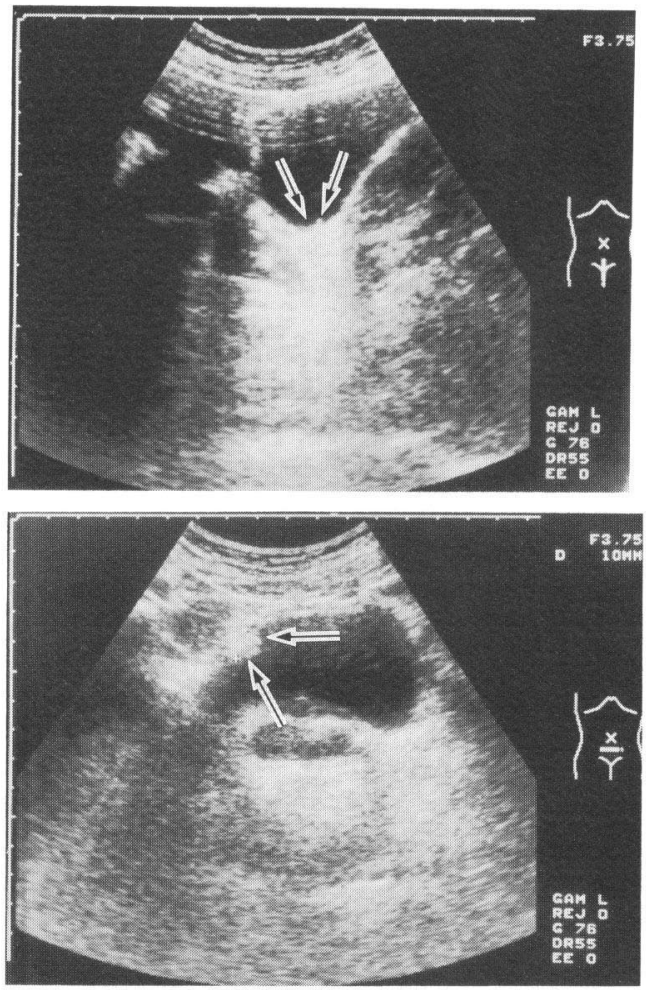

膀胱腫瘍切除術を行ったところ，いずれも表在性膀胱 癌であった，膀胼癌10例はいずれも無症状で，尿潜血 は 1 例のみが陽性であり，尿細胞診を検索した 8 例は 全て class II 以下であった。膀胱の超音波所見として はその他に，結石 3 例，狉室14例が認められた。

(4) 前立腺の超音波所見（表 6 ）

前立腺癌を疑わせる所見は 1 例に認められたが精査 の結果, 前立腺囊胞と考兄られた。前立腺石灰化は 2,011 例 $(28.8 \%)$ で認められ，最多の所見であった。
図 851 歳男性. 膀脂癌. 膀胱底部に内腔に突出する 腫瘍を認める (矢印)。

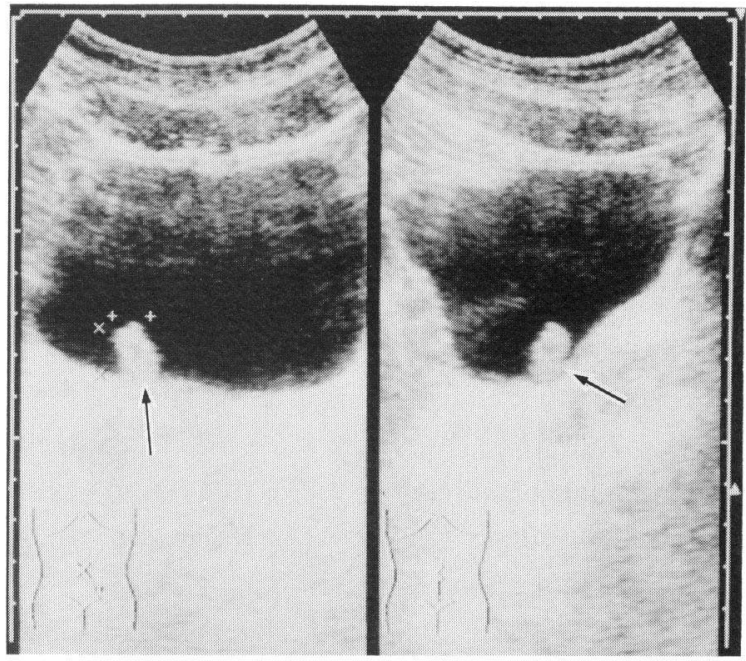

表 6 前立腺の経腹的超音波検査所見

\begin{tabular}{c|c|c|c}
\hline 潜 血 & 陰 性 & 陽 性 & 合 計 \\
\hline 腫 瘍 & 1 & & 1 \\
& $(0.01)$ & & $(0.01)$ \\
肥大症 & 330 & 11 & 341 \\
& $(4.86)$ & $(5.79)$ & $(4.88)$ \\
石灰化 & 1969 & 42 & 2011 \\
& $(29.0)$ & $(22.1)$ & $(28.8)$ \\
囊 胞 & 120 & 6 & 126 \\
& $(1.77)$ & $(3.16)$ & $(180)$ \\
\hline \multicolumn{4}{|c}{ 注 ; ( ) 内\% }
\end{tabular}

考察

人間ドックで腹部超音波検査が導入されて以来, 肝 蔵・胆囊・膵蔵をはじめとして, 腎臓・膀胱等の早期 癌発見の報告が散見される ${ }^{4)-7)}$. 尿路疾患のスクリー ニング検査としては集団健診での尿潜血が一般的であ り, 尿潜血陽性者の内, 悪性腫瘍の発見される割合は, Mohr ら ${ }^{1}$ によれが $0.5 \%$ (対象は35歳以上の男性と55 歳以上の女性), Messing ら²によれば2.2\%(対象は50 歳以上の男性）といわれている。しかし，尿潜血のみ 
では質的診断が困難であるのに対し4)，超音波検査は 形態的診断ができるため, 腎臓や膀胼の占拠性病変の 早期診断といら点では尿潜血に比肩しうる有用性があ るものと考えられる。

腎癌に関しては，対象とする集団が一定ではないも のの, 超音波検査による発見率は $0.01 \sim 0.3 \%$ で, $0.1 \%$ 前後とする報告が多(、4) 7). 三方ら ${ }^{8)}$ とよると，この率 は，本邦の腎癌発生率の約50倍とされている。

人間ドック等で偶然に発見される腎癌を, 五十嵐 ら9は Incidental renal cell carcinoma と呼んでいる。 Incidental renal cell carcinoma は全腎癌の $25 \%$ $(13.4 \sim 48 \%)^{9)}$ ，腎に限局する腎癌の $66 \%{ }^{10)}$ に登ると される. Incidental renal cell carcinoma の発見の契 機は, 五十嵐ら ${ }^{9}$ の腎摘除術を施行した 41 例の Incidental renal cell carcinoma の集計によると，腎癌とは関 係ない内科疾患等の精査中が $68.3 \%$ ，人間ドックが $24.4 \%$, 集団検診が $7.3 \%$ とされている.また, Aso ら ${ }^{11}$ の 1,428 例の集計では, 腎癌と関係ない内科疾患等の精 査中が $67.2 \%$, 人間ドックが $32.8 \%$ とされている. Incidental renal cell carcinoma の発見は超音波検査によ

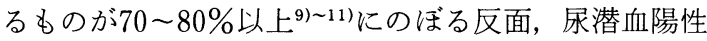
が発見の契機となっているのは $5 \%$ に満たないといわ れている910)。 また， Incidental renal cell carcinoma の内で尿潜血陽性となるのは $20 \%$ 程度9)しかないこと も考慮すると，この癌の発見には尿潜血より超音波検 查の方が有用と考兄られる. Incidental renal cell carcinoma は Non-incidental renal cell carcinoma に比

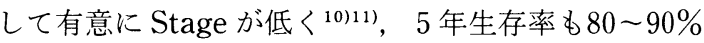
と報告されている ${ }^{9) 111}$. 自験例 2 例もいずれも Stage $\mathrm{I}($ Robson), pT2pN0pV0であり治癒切除が可能であっ た.

Incidental renal cell carcinoma の治療として Nephron sparing surgery（腎部分切除）が有用であり， 症例の選択を慎重に行兄ば長期予後も根治的腎摘除術 に比肩しらるとする報告もある ${ }^{12)}$ ，腎癌に対する腎部 分切除の適応についてはまだ統一された見解はない が, Herrlinger ら ${ }^{13)}$ は, 腫瘍の直径が3〜 $4 \mathrm{~cm}$ 以下の時 には low gradeで転移のない場合がほとんどである ことを指摘しておう，このような大きさの Incidental renal cell carcinoma に対しては腎部分切除が有用で ある可能性があると考号られる。今回, 我々は従来通 りの根治的腎摘除術を施行したがいずれも $\mathrm{pT}$ ， grade II であったことから，今後このようなIncidental renal cell carcinoma に対しては, 腎部分切除の実
施も考慮しょうと考えている。

腎癌の集団検診として腹部超音波検査を行うこと は, 腎癌の発生率が 3.5 人 $/ 10$ 万人 ${ }^{10)}$ と低いことから考 えて Cost-benefit が不良であり ${ }^{10)}$ ，Thompson ら ${ }^{10}$ は Case findings の方が重要であるとしている. 先に述べ た五十嵐らの集計では, Incidental renal cell carcinoma の患者の内で泌尿器科を初診科としたものは $14.6 \%$ という結果であり, 河邊は ${ }^{14)}$, Incidental renal cell carcinoma の患者が，ほとんどの場合泌尿器科以 外の科を初診することから，何らかの理由で医療機関 を受診した45歳以上の患者では, 腹部超音波検查を施 行すべきであるとしている。しかし，Thompson ら ${ }^{10)}$ も指摘しているょうに, 超音波検查は偽陰性所見は少 ないがベルタン柱や dromedary humps 等の偽陽性所 見が多く，自験例でも精査を行った15例中13例が偽陽 性と考えられた。偽陽性については, 診断精度の向上 のみで対応するのは限界があり，腎癌の超音波による スクリーニングといら観点からはある程度仕方がない ものと考えている.

その他の腎臓の超音波所見では, 文献上4) 7), 腎囊胞 (4.6 17.4\%)・腎結石 $(0.4 \sim 2.7 \%) \cdot$ 水腎症 $(0.1 \sim 1.5 \%)$ が多く, 自験例でも同様の傾向が認めら れた。 また，腎血管筋脂肪腫は長尾ら ${ }^{5)}$ にると $0.03 \%$ と報告されており，自験例（0.07\%）も同程度であっ た.

膀腅腫瘍の超音波検查での発見率は $0.01 \sim 0.02 \%{ }^{15)}$ で発見される腫瘍のほとんどが low-grade, low-stage

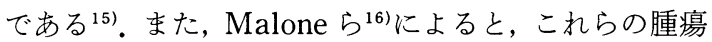
の超音波検査での detection rate は約 $50 \%$ と報告され

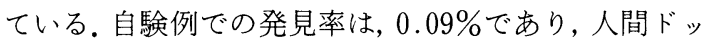
クの腹部超音波検查では, 膀脱充満下に下部尿路も走 査することは膀脱癌発見の点から有用であると考兄ら れた。

超音波検査上, 偽陽性所見は $11 \%$ 程度で ${ }^{16)}$, その内容 は膀胱炎などであり，偽陰性所見は前壁・頂部の腫瘍 や平坦な腫瘍に多いとされる 例に偽陽性所見が認められ, 検査時の充分な膀胱充満 と再検時の膀胱鏡検査は必須であると考兄られた。

膀胱癌10例中, 手術を施行した 7 例が全例表在性膀 脱癌であり，尿細胞診を行った 8 例は全て陰性で，尿 潜血陽性は10例中 1 例に認められただけであった。 Berlec ら ${ }^{17)}$ は, 表在性膀胱癌の診断には尿細胞診より 腹部超音波検查の方が優れているとしており，肉眼的 血尿や高度の顕微鏡的血尿を呈さない無症候性表在性 
膀胱腫瘍の早期発見には，尿潜血・尿細胞診よりも超 音波検査の方が有用であることが示唆された。

前立腺癌は発見されず，腹部超音波検査の久では前 立腺癌のスクリーニングとして不十分であると考兄ら れた。前立腺癌のスクリーニングには，文献上，直腸 診・経直腸エコー・PSA が使用されており年，いずれ も人間ドックへの導入は不可能ではないと思われる。

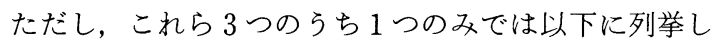
たような理由でスクリーニングとしては不十分で， 2 つ以上を組み合わせる必要があるとする報告もあ る ${ }^{19)}$.

直腸診は特別の装置を必要としないが感度の点で問 題がある18).

Stamey ${ }^{18)}$ は, 経直腸エコーが peripheral zone と central zone の impalpable carcinoma の診断に有効 な反面, hypoechoic lesion $の$ 非特異性や, 癌の 20 25\%が isoechoicであり, 癌の $20 \%$ が transition zone 由来であるためこれらを見落としてしまう可能 性がある等の問題点があることを指摘している，さら に，この検査のみを行った場合，Catalona ら ${ }^{20)} 443 \%$ の癌を見落とす可能性があり, Stamey ${ }^{18)}$ は 1 つの癌の 発見に536回の経直腸エコーが必要となるとしている。

PSA は客観的な指標であり, 多くの患者は前述の検 查より採血の方を好む傾向がある20)とはい光，直腸診 や経直腸エコーと比較してより有用かどらかの結論は

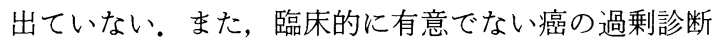
の可能性や, PSA の cut-off 值によって割合は違らが, PSAの正常な癌の存在も指摘されている ${ }^{211}$.

超音波検査という観点からは，すでに渡辺ら 22)が経 直腸エコーを 55 歳以上の 3,050 人の 1 次検診に用い, 前 立腺癌18例 $(0.6 \%)$ を検出するといら画期的な報告を 発表している。この報告と, 我々の結果とを比較する と, 経腹的超音波検査は下部尿路疾患のスクリーニン グといっても膀脱までが限界であり, 前立腺疾患のス クリーニングには有用でないと考えられた。しかし， 人間ドックで直腸診・経直腸エコー・PSA 等の検査を 施行すべきか否かは, 受診者の年齢分布や検查の費 用・簡便性, 人間ドックの検査に携わるスタッフの質・ 量などの他, 日本での前立腺癌の疫学的事項等も含め て考慮すべきと思われ，今後これらの点を検討してゆ く必要があると考えられた。

\section{結 語}

1. 1989年 8 月から1992年12月までに水戸済生会総 合病院健診センターを受診した男 6,981 名, 女4,405名,
合計 11,386 名の尿潜血预よび超音波検査の結果を集計 した。

2. 尿潜血は男性190名, 女性503名に認められ, 各年 齢層とも女性に多い傾向があった。

3. 腎腫瘍を疑われた23例中15例が精査のために再 受診し,この内 2 例に早期の腎癌が発見された.

4. 膀胖腫瘍を疑われた 20 例中 17 例が精查のために 再受診し, この内 10 例に膀胱癌が認められた。手術を 行いえた膀脱癌は 7 例で, 全例表在性であった。

5. 前立腺癌は発見されず, 経腹的超音波検査は前立 腺疾患のスクリーニングとしては有用性に限界がある と考えられた。

稿を終えるにあたり多大な御協力を頂いた水戸済生会総 合病院放射線科, 安藤桂恵子様並びに健診センター門馬勇 次先生及び各位に深謝致します。

本論文の要旨は第16回日本泌尿器科学会茨城地方会並び に第58回日本泌尿器科学会東部総会に扔いて発表した。

\section{文 献}

1) Mohr, D.N., Offord, K.P., Owen, R.A. and Melton, L.J. III : Asymptomatic microhematuria and urologic disease. J.A.M.A., 11, 224-229, 1986.

2) Messing, E.M., Young, T.B., Hunt, V.B., Emoto, S.E. and Wehbie, J.M.: The significance of asymptomatic microhematuria in men 50 or more years old: Findings of a home screening study using urinary dipsticks. J. Urol., 137, 919-922, 1987.

3）島居 徹, 笠谷俊也, 今田世紀：人間ドックの経腹 的超音波検查で発見された膀胼腫瘍. 日泌尿会誌, 83, 1847-1851, 1992.

4）宮沢紀子, 斉藤明美, 伊藤敏子, 富樫凡子, 石川悦 子, 戸堀文雄, 井上義朗, 畑沢 実: 腹部超音波検 查の腎所見と尿検査との関連についての検討，健 康医学，4，19-22, 1989.

5）小西憲子, 山田良久：尿異常者のスクリーニング. 日腎誌，27，243-247，1985。

6）長尾玲子，宮川 寬，池上文詔，野田正信：人間 ドックに抢ける腹部超音波検查 5 年間の成績検 討. 健康医学, 4, 33-37, 1989.

7）島川直樹, 口石優子, 千住雅博, 神谷直昭, 森 信 興, 後藤健治, 寺崎昌幸: 人間ドックにおける腹部 超音波検查の現況 (第 1 報). 医学検査, 40 , 1010-1014, 1991.

8）三方律治, 今尾貞夫, 堀内大太郎, 田中良典, 松元 元一, 長谷川和則：検診を契機に超音波走査で発 見された腎癌とそのMRI.癌の臨床, 34, 1049-1053, 1988.

9）五十嵐辰男, 村上信乃, 富岡 進, 阿部功一, 井坂 
茂夫, 岡野達郎, 島崎 淳, 松菩 理: 偶然飞発見 された腎癌の検討，日泌尿会誌，80，1310-1315， 1989.

10) Thompson, I.M. and Peek, M.: Improvement in survival of patients with renal cell carcinoma - The role of the serendipitously detected tumor. J. Urol., 140, 487-490, 1988.

11) Aso, Y. and Homma, Y.: A survey on incidental renal cell carcinoma in Japan. J. Urol., 147, 340-343, 1992.

12) Moll, V., Becht, E. and Ziegler, M.: Kidney preserving surgery in renal cell tumors : Indications, techniques and results in 152 patients. J. Urol., 150, 319-323, 1993.

13) Herrlinger, A., Schott, G., Schafhauser, W. and Schrott, K.M. : Die Bedeultung des Tumordurchmessers beim Nierenzellkarzin om. Urology A, 31, 70, 1992.

14）河邊香月：偶然発見された腎細胞癌。臨泌，42, 1045-1054, 1988.

15）麦谷茫一, 鈴木俊秀, 田島 嵉, 関口 浩, 金子桂 雄, 秋山敏一, 杉山 高, 阿曾佳郎：膀脱腫瘍早期 診断に括ける経腹壁的超音波断層法の有用性につ いて。 日泌尿会誌, 79，847-852，1988.

16) Malone, P.R., Weston-Underwood, J., Aron, P. M., Wilkinson, K.W., Joseph, A.E.A. and Riddle, P.R.: The use of transabdominal ultrasound in the detectin of early bladder tumors. Br. J. Urol., 58, 520-522, 1986.

17) Berlac, P.A. and Holm, H.H.: Bladder tumor control by abdominal ultrasound and urine cytology. J. Urol., 147, 1510-1512, 1992.

18) Stamey, T.A.: Diagnosis of prostate cancer: A personal view. J. Urol., 147, 830-832, 1992.

19) Cooner, W.H., Mosley, B.R., Rutherford, C.L. Jr., Beard, J.H., Pond, H.S., Terry, W.J., Igel, T. C. and Kidd, D.D.: Prostate cancer detection in a clinical urological practice by ultrasonography, digital rectal examination and prostate specific antigen. J. Urol., 143, 1146-1154, 1990.

20) Catalona, W.J., Smith, D.S., Patlife, T.L., Dodds, K.M., Coplen, D.E., Yuan, J.J.J., Petros, J.A. and Andriole, G.E.: Measurement of prostate-specific antigen in serum as a screening test for prostate cancer. N. Engl. J. Med., 324, 1156-1161, 1991.

21) Brawer, M.K., Chetner, P., Beatie, J., Buchner, D.M., Vessella, R.L. and Lange, P.H. : Screening for prostatic carcinoma with prostate specific antigen. J. Urol., 147, 841-845, 1992.

22）渡辺 決, 大江 宏, 斉藤雅人, 板倉康啓, 中尾昌 宏：経直腸的超音波断層法を用いた前立腺集団検 診の現況. 日泌尿会誌，76，913-920， 1985. （1993年11月 12 日受付，1994年 3 月 28 日受理） 